\title{
Program Manajemen Stres Kerja di Perusahaan: sebuah Petunjuk untuk Menerapkannya
}

\author{
Susy Purnawati ${ }^{1}$ \\ Bagian Ilmu Faal Fakultas Kedokteran Universitas Udayana, Denpasar Bali
}

\begin{abstract}
Job stress is an iceberg phenomen. A great number of unreported cases and there is no aplicative program in Indonesia cause increase of job stress risk and its negative impact to productivity and company image. More complex job demand without appropriate work capacity and inharmonic relationship in the work place could be the main sources of job stress. This paper is focused on job stress management program guidance that applicable at company and physiologic stress response and also in depth theoretical point of job stress management within psycho-physiology aspect. The aim of this written paper is to increase awareness and understanding of the application of stress management programs among occupational physician, industrial community and industrial practices. Stress management programs in company not only post about the improvement of working conditions also focuses on an individual orientation. On aspects of working conditions, the improvement should be referring to standard of occupational health and safety (OHS) management program, while aspect of individual coping skills can be done with the training of problem focus technique. Several studies have shown that the program creates respond to the limbic system of brain which is integrated with the function of cortex frontals. In addition, it could create respond to changes body's homeostasis due to changes in the response of the limbic system to the HPA (hypothalamic - pituitary - adrenal) axis and SAM (symphato - Adreno - medullary) - axis. The effectiveness of the program can be measured by the subjective and objective parameters.
\end{abstract}

Keywords: stress management programs, job performance, company image

Stres kerja (job stress) merupakan sebuah fenomena gunung es. Banyaknya kasus-kasus yang tidak terlaporkan dan berisiko makin meluasnya masalah stres kerja dengan segala dampak negatifnya di masyarakat. Tuntutan beban tugas yang semakin kompleks disertai relationship yang tidak harmonis di tempat kerja merupakan sumber utama timbulnya stres pada pekerja. Stres kerja harus dikenali sedini mungkin untuk kemudian dikelola dengan benar. Sampai saat ini berbagai program manajemen stres telah diperkenalkan oleh para pakar kesehatan kerja

\footnotetext{
${ }^{1}$ Korespondensi mengenai isi artikel ini dapat melalui: s_purnawati@yahoo.com
}

dan industri. Akan tetapi, masih banyak program yang masih memiliki kelemahan karena cakupan program tidak memuat aspek perbaikan kondisi kerja. Selain itu, informasi-informasi mencakup mekanisme perubahan dalam tubuh yang diharapkan terjadi setelah diaplikasikannya program ataupun dampak dari stres kerja secara biologi belum disajikan secara mendalam. Kajian dampak stres kerja dari aspek biologi akan memberi acuan untuk dapat mengukur dampak stres kerja melalui pengukuran secara objektif serta bermanfaat untuk dapat melakukan penanganan secara lebih dini. 
Idealnya program manajemen stres kerja mencakup pencegahan primer (bersifat mencakup promosi kesehatan), sekunder (bersifat mencakup pengobatan secara klinis) dan tersier (bersifat mencakup program rehabilitasi). Jenis program manajemen stres kerja yang dibahas dalam makalah ini merupakan pencegahan stres kerja yang bersifat pencegahan primer. Memuat hal-hal sebagai berikut: (1) Pendekatan organisasi (improvement of psychosocial environment); (2) Education/ training of managers and supervisors; (3) Individualoriented stress management (Shimazu, 2006; Kawakami, 2010). Pada prinsipnya, aspek pendekatan organisasi dilakukan dengan melakukan perbaikan kondisi kerja dengan mengacu pada standar occupational health and safety (OHS) -management program, yang di dalamnya juga memuat penerapan norma-norma kerja (yang dikenal sebagai penerapan bidang ilmu ergonomi). Sedangkan dua fokus program yang lain yaitu Aducation/training of managers and Individual-oriented dilakukan dengan pelatihan-pelatihan yang berorientasi untuk pemberdayaan coping skill individu (pekerja).

Studi pustaka ini bertujuan untuk meningkatkan awarenes dan pemahaman tentang pentingnya penerapan program manajemen stres kerja pada masyarakat industri baik industri formal maupun non formal dalam menunjang produktivitas kerja. Beberapa pertanyaan penelitian yang ingin dijawab adalah: (1) Bagaimanakah perkembangan teori-teori tentang stres kerja yang relevan secara epidemiologi (ilmu perkembangan penyakit)?

Bagaimanakah acuannya jika ingin melaksanakan program manajemen stres kerja di perusahaan? dan (3) Bagaimanakah gambaran efek program manajemen stres kerja terhadap tubuh ditinjau dari aspek phycophysiology?

Perkembangan Teori-Teori tentang Stres Kerja

Perkembangan studi-studi tentang stres kerja dewasa ini tidak terlepas dari konsep teori tentang stres kerja yang pertama kali dipopulerkan oleh Karasek pada tahun 1979. Konsep Karasek ini dikenal sebagai the job demands-control (JDC) model atau deman-control-support (DCS) model (Kawakami, 2010a; Inoue, 2010). Model lainnya masing-masing adalah NIOSH job stress model (Hurrel \& McLaney, 1988), Effort-reward imballance (ERI) model (Siegrist, 1996), dan sebuah konsep yang dikenal sebagai Organizational Justice Concept (Inoue, 2010), konsep ini melengkapi JD-C model dan ERI model. Dalam NIOSH model, teori tentang stres kerja mengacu pada konsep yang secara skematis dapat dilihat dalam pada Gambar 1.

Gambar 1 menggambarkan bahwa stresor yang dihubungkan dengan pekerjaan adalah kondisi-kondisi kerja yang memicu reaksi-reaksi akut, atau strainstrain pada pekerja. Reaksi-reaksi tersebut menggambarkan dominan atau tidaknya respon-respon fisiologis maupun perilaku. Reaksi-reaksi tersebut menggambarkan dominan atau tidaknya respon-respon fisiologis maupun perilaku. Berbagai jenis job stressor dapat diubah oleh faktor individu dan adanya dukungan baik dari supervisor, teman sekerja dan keluarga (yang berperan sebagai buffering factors) kemudian akan memengaruhi reaksireaksi stres yang timbul. Reaksi-reaksi tersebut dapat berupa reaksi psikologis, fisik maupun perilaku yang berperan dalam tendensi timbulnya penyakit ataupun cedera. 


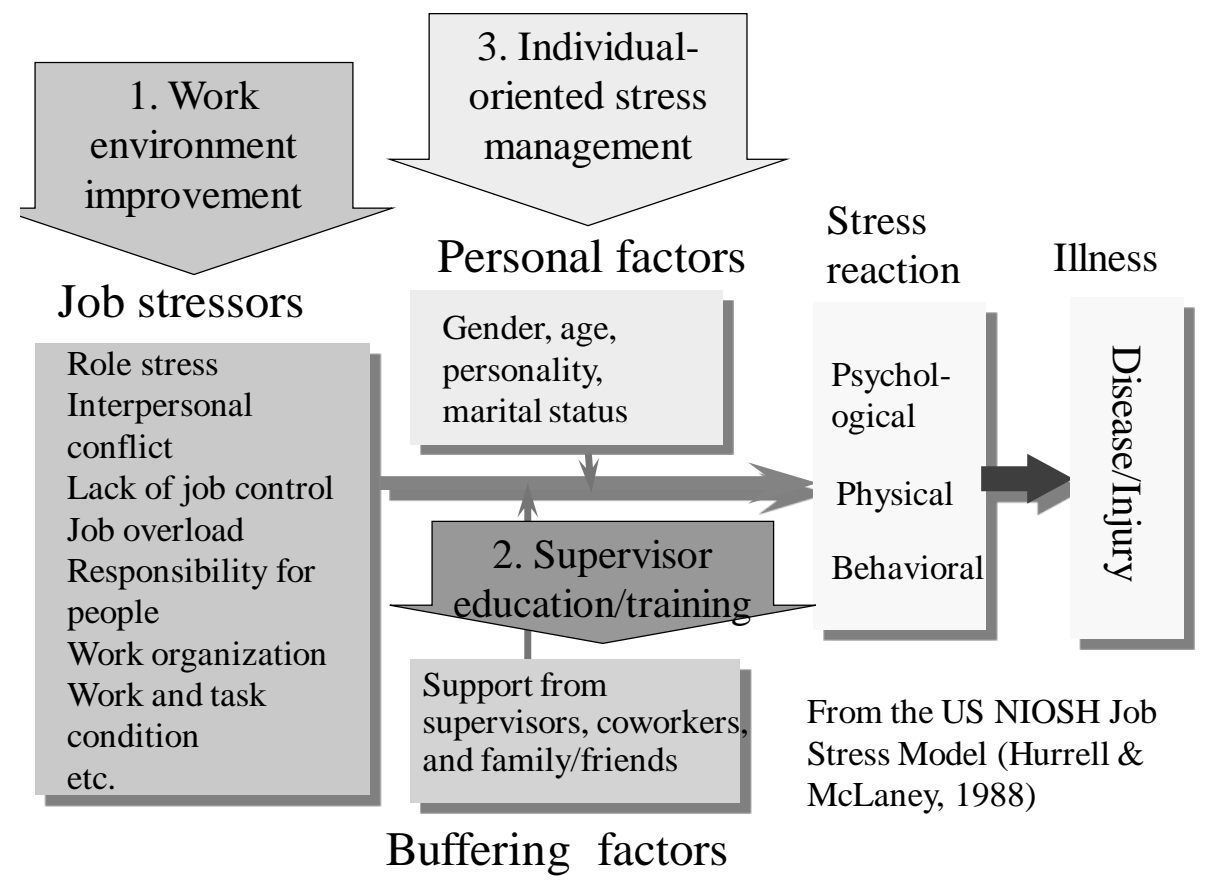

Gambar 1. NIOSH Model, Teori tentang Stres Kerja

Beberapa model stres kerja yang diuraikan di atas kemudian menjadi acuan penyusunan instrumen-instrumen penilai beberapa parameter yang berhubungan dengan stres kerja, contohnya adalah Brief Job Stress Questionnaire (BJSQ) yang disusun mengacu pada NIOSH job stress model.

Penulis telah melakukan uji coba penerapan Ergo-JSI (di sebuah bank swasta di Denpasar), yang merupakan sebuah contoh program manajemen stres kerja dengan pendekatan organisasi dan berorientasi individu (Purnawati, 2011). Program ini mencakup perbaikan kondisi kerja secara umum dan peningkatan kemampuan coping individu. Dalam program, kondisi kerja karyawan diperbaiki dengan pengaturan istirahat aktif dengan melakukan peregangan di tempat kerja, perbaikan sistem pengamanan data komputerisasi perbankan, serta diberikan training dalam kelas selama delapan minggu mencakup topik-topik diantaranya: cognitive restructuring, assertive skill dan time management skill. Salah satu hasil dari intervensi tersebut adalah secara signifikan dapat meningkatkan kepuasan kerja karyawan (Purnawati, 2012).

Acuan-Acuan dalam Melaksanakan Program Manajemen Stres Kerja di Perusahaan

Sehubungan dengan pelaksanaan program manajemen stres kerja di perusahaan perlu dirinci beberapa hal yang merupakan cakupan dari program. Secara garis besarnya, program manajemen stres kerja diharapkan memuat perbaikan kondisi kerja serta pelatihan-pelatihan yang bersifat individual oriented. Secara umum, perbaikan kondisi kerja dilakukan dengan pendekatan ergonomi (yaitu sebuah disiplin ilmu tentang norma-norma kerja), yang juga dikenal sebagai pendekatan organisasi. Sedangkan peningkatan kemampuan coping individu dapat dilakukan dengan peningkatan beberapa keterampilan dalam mengantisipasi job stress secara internal. Kegiatan persiapan pelaksanaan program dimulai dari analisis kondisi kerja dan evaluasi kondisi stres kerja individu (serta kondisi kesehatan, khususnya mental secara umum). 
Kegiatan analisis kondisi kerja dapat menggunakan mental health action check list (MHACL) (Yoshikawa, Kawakami, Kogi, Tsutsumi, Shimazu, Nagami, \& Shimazu, 2007) ataupun menggunakan acuan ergonomics check point (ILO, 2010), dan penilaian individu dilakukan menggunakan kuesioner serta pemeriksaan kesehatan umum. Kuesioner yang dapat digunakan sangat beragam tergantung teori job stres model yang diacu. Berdasarkan hasil analisis kondisi kerja dan individu kemudian disusun program manajemen stres yang sesuai yang dirancang secara partisipatori bersama pihak perusahaan/ industri. Hal tersebut bertujuan agar program dapat mencerminkan the workers and employer's need. Dalam program tersebut, perbaikan kondisi kerja yang mengacu pada pendekatan ergonomi mencakup aspek tugas, organisasi maupun lingkungan kerja. Misalnya, perbaikan kondisi kerja di industri perbank-an dapat dilakukan dengan menerapkan hal-hal berikut, yaitu: kenali kondisi dan lingkungan kerja yang bisa mencetuskan stres lalu temukan solusi perbaikannya, pemberdayaan local good practice (Kogi, 2010), diskusikan dengan supervisor, kolega, dokter perusahaan, maupun staf human resource development (HRD), terapkan budaya perbaikan tiada henti ("Kaizen"), deskripsi kerja disusun secara jelas dan disosialisasikan, menciptakan social support yang baik antar karyawan dan karyawan dan supervisor, maksimalkan peran bagian electronic data processing (EDP) untuk menjamin tidak ada stres teknologi dan aplikasi software perbank-an yang user friendly.

Selain perbaikan kondisi kerja, dalam program manajemen stres kerja juga dilakukan pelatihan-pelatihan untuk pemberdayaan mekanisme coping individu atau pekerja. Dalam pelatihan tersebut diupayakan ruang belajar dan pengaturan strategi pembelajaran dibuat ergonomis, dan dilengkapi dengan buku suplemen pembelajaran. Topik-topik yang diajarkan disesuaikan dengan stresor yang ada dan maturitas/status pendidikan individu (karyawan). Beberapa topik yang sesuai untuk diajarkan diantaranya: mengenali dan menata emosi, pikiran dan perilaku, keterampilan time management, problem focus technique dan assertive skill/ communication skill (Shimazu, 2010). Selain itu juga diajarkan teknik relaksasi yang salah satu contohnya dapat dalam bentuk progressive muscle relaxation (Smith, 2002).

Evaluasi keberhasilan program dapat dinilai dari peningkatan penampilan kerja ataupun produktivitas kerja. Selain itu juga dapat dinilai menggunakan beberapa paramater lain (misalnya self efficacy, stresor dan distres psikologi dari kuesioner BJSQ, kuesioner Nordic Body Map dan keluhan muskulo-skeletal/fisik lainnya, dan beberapa marker biologi dari pemeriksaan darah/urin/saliva) (Theorell, Emdad, Arnetz, \& Weingarten, 2001; Appels \& Kop, 2007; Bellingrat, Weigl, \& Kudielka, 2009; Maina, Bovenzi, Palmas, \& Filon 2009; Den, Toda, Ohira, \& Kanehisa, 2011). Agar lebih akurat pengukuranpengukuran efektivitas program sebaiknya dilakukan sebelum dan sesudah pelaksanaan program.

Efektivitas program tentunya harus dapat dipertanggungjawabkan biological plausibility-nya agar lebih bisa diyakini dan nantinya bisa diterapkan secara lebih luas. Paparan berikut menjelaskan manfaat nyata program manajemen stres kerja yang dihubungkan dengan mekanisme biologi dalam tubuh maupun sebagai tinjauan dalam bidang organisasi.

Dari sisi tinjauan organisasi, program manajemen stres kerja yang memuat aspek perbaikan kondisi kerja, secara tidak langsung dapat berefek pada image karyawan 
terhadap organisasinya. Atau dengan kata lain berefek pada terbentuknya citizenshif behavior organization yang lebih positif. Kobayashi, Kaneyoshi, Yokota, \& Kawakami (2008) menemukan adanya perubahan aspek intrinsik rewards pada karyawan, setelah dilakukan perbaikan kondisi kerja. Dalam penelitiannya Kobayashi dan kawan kawan menerapkan perbaikan kondisi kerja yang didahului dengan workshop dan diikuti perubahan kondisi kerja selama setahun.

Dalam program manajemen stres kerja, diharapkan materi-materi pelatihan untuk meningkatkan coping skill dapat memberi efek sampai kepada core belief individu. Menurut Borrins (2011), intervensi informasi-informasi yang sampai mampu menyentuh kepada core belief individu melalui cogtitive restructuring dapat mengarahkan individu untuk mengubah mood yang negatif dan cara berpikir yang salah (distorsi) menjadi individu yang selalu berpikir dan berperasaan (memiliki mood) yang lebih positif, sehingga pada akhirnya berperilaku yang lebih positif terhadap pencetus stres yang berhubungan dengan efek tuntutan beban pekerjaan. Individu akan mampu berkomunikasi, mengekspresikan apa yang dirasakannya dengan tetap menghargai hak-hak dan perasaan orang lain (Silverman, Kurtz, \& Draper, 1998). Individu yang lebih mengerti tentang situasi emosi dan pikiran yang dialaminya tentunya akan memiliki keterampilan coping yang lebih baik. Hal tersebut terjadi karena dirasakan persepsi yang berbeda pada sistem limbik otak yang terintegrasi dengan pusat kognitif di area korteks otak bagian depan. Responnya akan menurunkan respon stres yang negatif dan akhirnya muncul respon yang lebih positif (Lloyd \& Bor, 1996). Respon stres yang negatif tentunya sangat merugikan dalam hal performance kognitif atau fungsi intelegensi karyawan. Penurunan fungsi kognitif merupakan ancaman terhadap penampilan kerja. Selain itu, buruknya konsentrasi, ketidakmampuan dalam pengambilan keputusan, mental block, dan penurunan rentang perhatian muncul akibat stres kerja. Program manajemen stres kerja memberi media bagi usulan perbaikan, dan pelatihan menata emosi dan pikiran mempunyai efek peningkatan penampilan kerja yang mencakup juga pengambilan keputusankeputusan yang kompleks (Guyton \& Hall 2006). Rangsangan pada pusat emosi yang berlokasi pada sistem limbik di midbasal otak dapat memengaruhi area Wernicke, yaitu area pikiran kompleks termasuk ingatan yang rumit dan memengaruhi fungsi kognitif yang juga berperan dalam pengambilan keputusan/performance. Secara detil, optimalisasi fungsi intelektual di area tersebut mencakup: kemampuan memecahkan masalah kompleks, mengantisipasi beberapa aktivitas kompleks secara simultan, perasaan yang mampu bersaing, mampu berpikir yang lama, emosi stabil, aktivitas-aktivitas fisik lebih bertujuan, respon sosial yang lebih sesuai, tingkah laku lebih terkendali (karena area otak tersebut berhubungan dengan korteks asosiasi limbik), performance kemampuan kognitif sangat cemerlang (berpikir, menganalisis tingkat tinggi, proses berpikir dengan urutan yang logis dengan cepat, lebih cepat menyelesaikan tugas atau tujuan tanpa rasa bingung, berperan dalam ingatan aktif, yaitu kemampuan untuk memperkirakan masa depan, membuat rencana untuk masa yang akan datang, perlambatan kerja sebagai respon terhadap sinyal sensorik yang masuk sehingga informasi sensorik ini dapat dipertimbangkan sampai bentuk respon yang terbaik diputuskan, mempertimbangkan akibat kerja motorik bahkan sebelum kerja tersebut dilakukan, menye- 
lesaikan masalah yang kompleks, menganalisis fenomena dan mengendalikan aktivitas dalam kaitannya dengan hukum dan moral (Guyton \& Hall, 2006).

\section{Efek Program Manajemen Stres Kerja Ditinjau} dari Aspek Phsyco-Physiology

Manfaat dari penerapan manajemen stres kerja secara phsycho-physiology selain dapat diukur secara subjektif menggunakan kuesioner-kuesioner terbukti menurunkan kortisol darah. Kortisol yang tinggi dalam darah akibat stres kerja dapat berakibat timbulnya berbagai masalah kesehatan dan penampilan kerja, di antaranya: (a) meningkatkan lemak abdomen; (b) gangguan penampilan kognitif; (c) meningkatkan kadar gula darah; (d) menurunkan densitas tulang; (e) meningkatkan tekanan darah; dan (f) menurunkan imunitas tubuh dan respon terhadap inflamasi dengan berbagai konsekuensinya (Hansson, Vingard, Arnetz, \& Anderzen, 2008). Seperti telah diuraikan dalam paparan sebelumnya, peningkatan kadar kortisol dalam tubuh diatur oleh mekanisme kontrol yang melibatkan pusatpusat kontrol di otak maupun oleh kadar kortisol sendiri di dalam darah. Stres mental dapat juga segera menyebabkan peningkatan sekresi ACTH. Keadaan ini dianggap sebagai akibat dari naiknya aktivitas dalam sistem limbik, khususnya dalam regio amigdala dan hipokampus, yang keduanya kemudian menjalankan sinyal ke bagian posterior medial hipotalamus (Guyton \& Hall, 2006).

Berbagai stres dapat mengaktifkan seluruh sistem yang menyebabkan timbulnya pelepasan kortisol dengan cepat, dan jika masih dalam rentang kondisi terkontrol kortisol ini selanjutnya akan menginduksi suatu rangkaian efek metabolisme yang akan langsung mengurangi sifat perusakan dari keadaan stres itu. Sebagai tambahan, juga ada umpan balik langsung dari kortisol terhadap hipotalamus dan kelenjar hipofisis anterior untuk menurunkan konsentrasi kortisol dalam plasma sewaktu tubuh tidak mengalami stres. Akan tetapi, rangsangan stres itu sebenarnya merupakan salah satu rangsangan terkuat. Rangsangan ini selalu dapat mematahkan umpan balik penghambat langsung dari kortisol, sehingga akan menyebabkan timbulnya eksaserbasi periodik dari sekresi kortisol pada berbagai waktu selama satu hari atau pemanjangan sekresi kortisol dalam keadaan stres kronik (Guyton \& Hall, 2006).

Ternyata sebagian besar stresor dalam kehidupan sehari-hari bersifat psikososial. Walaupun mobilisasi cepat sumbersumber daya tubuh memang tepat untuk menghadapi cedera fisik baik yang masih bersifat sebagai ancaman atau yang sudah terjadi. Secara umum hal tersebut kurang sesuai untuk respon terhadap stres non fisik. Apabila tidak diperlukan energi tambahan, tidak ada kerusakan jaringan, tidak ada pengeluaran darah maka penguraian cadangan energi tubuh dan retensi cairan merupakan tindakan yang sia-sia, bahkan merugikan bagi individu yang mengalami stres. Pada kenyataannya, terdapat bukti-bukti tidak langsung yang kuat, yang menghubungkan antara paparan stresor psikososial kronik dan berkembangnya keadaan patologis, misalnya aterosklerosis dan tekanan darah tinggi, walaupun hubungan sebab dan akibatnya masih perlu dibuktikan lebih lanjut. Akibat respon stres yang tidak digunakan akan dapat dijelaskan secara logis dampak yang dapat ditimbulkannya sehubungan dengan kondisi patologis yang muncul akibat stres tersebut (Guyton \& Hall, 2006). Penyimpangan sekresi kortisol dari pola siklus diurnal menjadi dasar informasi sehubungan dengan pengaruh ling- 
kungan, termasuk stres kerja, terhadap HPA-axis dan peran HPA-axis tersebut terhadap proses-proses penyakit (Stone, Schwartz, Smyth, Kirschbaum, Cohen, Hellhammer, \& Grossman, 2001).

Efek manajemen stres kerja berdampak kepada optimalnya fungsi kognitif area korteks frontalis serebri dan memberi respon lanjutan terhadap sistem hipotalamo-pituitary-adrenal (HPA)-axis dan simpato-adreno-medullary (SAM)-axis. Kedua axis ini menjadi terkontrol menuju kondisi homeostasis sehingga kadar kortisol darah menurun. Kondisi kortisol darah menuju keadaan homeostasis ini sangat dibutuhkan oleh karyawan yang memiliki kemungkinan-kemungkinan mengalami stres akut selama waktu kerja akibat tuntutan beban pekerjaan yang sifatnya kuantitatif maupun kualitatif. Lonjakan kadar kortisol darah karyawan yang telah mendapatkan program manajemen stres pada saat mengalami stres akut akibat faktor pekerjaan tentunya tidak sampai kepada kondisi yang patologis yang terutama berdampak kepada sistem metabolisme energi dan sistem imunitas tubuh.

Selain itu, program manajemen stres kerja secara biologi bermanfaat meningkatkan sistem imunitas tubuh (Hansson dkk., 2008) dan mencegah kerusakan endotel pembuluh darah serta meregulasi pengeluaran hormon stres yang berperan menimbulkan kekakuan pembuluh darah pada penyakit jantung koroner (Vlachopoulos, Kosmopoulou, Alexopoulos, Ioakeimidis, Siasos, \& Stefanadis, 2006). Theorel dkk. (2001) pada penelitian eksperimennya dengan intervensi berupa pemberian pelatihan manajemen stres dua kali seminggu masing-masing dua jam dalam tiap sesi selama setahun kepada supervisor perusahaan asuransi. Evolahti, Hultcrantz, dan Collins (2006) dalam studi longitudinalnya menemukan bahwa peningkatan awareness tentang kondisi psikososial di tempat kerja, peningkatan dukungan sosial dan pengaturan kembali tuntutan kerja yang tinggi dapat menurunkan kortisol darah.

Paparan di atas menggambarkan bagaimana pentingnya sebuah perusahaan atau organisasi melakukan upaya manajemen stres kerja sehingga stres kerja menurun dan penampilan kerja karyawan terutama kemampuan kognitif mereka menjadi optimal.

\section{Penutup}

Berdasarkan uraian di atas dapat disimpulkan bahwa: (1) Program manajemen stres kerja idealnya mencakup pencegahan primer, sekunder dan tersier yang aplikasinya disesuaikan dengan kondisi perusahaan; (2) Program manajemen stres harus mencerminkan the workers and employer's need agar dapat diaplikasikan secara berkesinambungan. Ergo-JSI merupakan sebuah program manajemen stres kerja yang mencakup perbaikan kondisi kerja dan berorientasi individu; (3) Penerapan ergonomi merupakan aspek yang sangat penting dalam program manajemen stres kerja, karena dapat menangani stres kerja secara lebih holistik.

\section{Daftar Pustaka}

Appels, A., \& Kop, W. J. (2007). Fatigue \& Stress. In: Encyclopedia of Stress. $2^{\text {nd }}$ Ed. Vol 2. USA: Elsevier Inc. 11-14.

Bellingrath, S., Weigl, T., \& Kudielka, G. M. (2009). Chronic work stress and exhaustion is associated with higher allostastic load in female school teachers. Stress. USA: Informa Health Care, 12(1), $37-48$. 
Borrins, M. (2011). Work related stress. Dalam materi guest lecture 22 Juli. Pusat Kajian Ergonomi, Laboratorium Ilmu Faal FK.UNUD. Denpasar.

Cooper, C. L., \& Payne, R. (1990). Causes, Coping and Consequences of Stress at Work. New York: John Wiley \& Sons.

Cox, T., \& Griffiths, A. (2005). The nature and measurement of work-related stress: theory and practice. In Evaluation of Human Work 3rd Ed. Wilson, J.R. and Corlett, N. Ed. USA: Taylor \& Francis.

Den, R., Toda, M., Ohira, M., \& Kanehisa, M. (2011). Levels of awakening salivary $\mathrm{CgA}$ in response to stress in healthy subjects. Environ Health Prev Med, 16, 155-157.

Evolahti, A., Hultcrantz, M., \& Collins, A. (2006). Women's work stress and cortisol levels: a longitudinal study of the association between the psychosocial work environment and serum cortisol. Journal of Psychosomatic Research, 61, 645- 652

Guyton \& Hall. (2006). Adrenocortical hormones. In Textbook of Medical Physiology $7^{\text {th }}$ ed. Philadelphia, Pensylvania: Elsevier Inc.

Hansson, A. S., Vingard, E., Arnetz, B. B., \& Anderzen, I. (2008). Organizational change, health, and sick leave among health care employees: a longitudinal study measuring stress markers, individual, and work site factors. Work $\mathcal{E}$ Stress, A Journal of Work, Health and Organization, 22(1), January-March.

Hurrell, J. J., \& McLaney, M. A. (19880. Exposure to job stress - a new psychometric instrument. Scand J Work Environ Health, 14 (suppl. 1): 27-28.

ILO. (2010). Ergonomics Checkpoints $2^{\text {nd }}$ Ed. Geneva:ILO.
Inoue, A. Kawakami, N., Masao, I., Shimazu, A., Tsuchiya, M., Tabata, M., Akiyama, M., Kitazume, A., \& Kuroda, M. (2010). Organizational justice, psychological distress, and work angagement in japanese workers. Int Arch Occup Environ Health, 83, 29-38.

Karasek, R. (1992). Stress Prevention through work reorganization: a summary of 19 international case studies. Condition of Work Digest 11, 2.

Kawakami, N. (2010). Job stress and mental health among workers in Asia and the world. J Occup Health, 52, 1-3.

Kobayashi, Y., Kaneyoshi, A., Yokota, A., \& Kawakami, N. (2008). Effects of worker participatory program for improving work environments on job stressors and mental health among workers: a controlled trial. Journal of Occupational Health, 50(6), 455-70

Kogi, K. (2008). Facilitating participatory steps for planning and implementing low-cost improvements in small workplaces. Elsevier. Applied Ergonomics, $39,475-481$.

Kompier, M., \& Cooper, C. (2008). Preventing Stress, Improving Productivity. NY: Taylor and Francis

Kroemer, K. H. E. (2009). Workload and stress. In Fitting the Human, Introduction to Ergonomics. USA: Taylor \& Francis. p. $235-245$.

Li, C. R., \& Sinha, R. (2008). Inhibitory control and emotional stress regulation. Neurosci Biobehav Rev, 32(3), 581-597.

Lloyd, M., \& Bor, R. (1996). Communication skills for medicine. NY: Pearson Professional Limited.

Maina, G., Bovenzi, M., Palmas, A., \& Filon, F. L. (2009). Associations 
between two job stress models and measures of salivary cortisol. Int Arch Occup Environ Health, 82, 1141 - 1150.

Montgomery, B. (2008). CBT. International Workshop on Clinical Skill for Cognitive Behavioral Therapy. Denpasar. April 22-24 ${ }^{\text {th }}$

NIOSH. (2008). Generic job stress questionnaire. Cincinnati: Institute for Occupational Safety and Health, Devision of Behavioral and Biomedical Sciences, Motivation and Stress Research Section.

Purnawati, S. (2011). Ergo-JSI sebuah program manajemen stres kerja berbasis ergonomi. Prosiding Seminar Nasional Ergonomi, PEI-UI, 14-15 September. Jakarta.

Purnawati, S. (2012). Ergonomics-Job Stress Intervension (Ergo-JSI) reduces stress of employees at National Bank in Denpasar. IJBS, 6(2), 59-65

Richardson, K. M., \& Rothstein, H. R. (2008). Effects of occupational stress management intervention programs: a meta-analysis. Journal of Occupational Health Psychology, 13(1), 69-93.

Shimazu, A. (2010). Lecture Material. Oktober. University of Tokyo, Japan.

Shimomitsu. (2000). The brief job stress questionnaire (BJSQ) for self-stress monitoring. In Kawakami, N. 2010. Assessment of job stress, lecture material. October. Tokyo University. Japan.

Siegrist, J. (1996). Adverse health effect of high-effort/low reward conditions. Journal of Occupational Health Psycho$\log y, 1,27-41$.

Silverman, J., Kurtz, S., \& Draper, J. (1998). Skill for communicating with patients. UK: Radcliffe Medical Press.
Smith, J. C. (2002). Stress Management, A Comprehensive Handbook of Techniques and Strategies. New York: Springer Publishing Company, Inc.

Stone, A. A., Scchwartz, J. E., Smyth, J., Kirschbaum, C., Cohen, S., Hellhammer, D., \& Grossman, S. (2001). Individual differences in diurnal cycle of salivary free cortisol: a replication of flattened cycles for some individuals. Psychoneuroendocrinolgy, 26, 295 - 306.

Theorell, T., Emdad, R., Arnetz, B., \& Weingarten, A. (2001). Employee effects of an educational program for managers at an insurance company. Psychosomatic Medicine, 63, 724-733.

Vlachopoulos, C., Kosmopoulou, F., Alexopoulos, N., Ioakeimidis, N., Siasos, G., \& Stefanadis, C. (2006). Acute mental stress has prolonged unfavorable effect on arterial stiffness and wave reflections. Psychosomatic Medicine, 68, 231-237.

Wada, K., Arimatsu, M., Higashi, T., Yoshikawa, T., Oda, S., Taniguchi, H., Kawashima, M., \& Aizawa, Y. (2009). Physician job satisfaction and working condition in Japan. Journal Occupational Health, 51, 261-266.

WHO. (2007). Raising awareness of stress at work in developing countries. In: Protecting Workers'Health Series, 6. Geneva.

Yoshikawa, T., Kawakami, N., Kogi, K., Tsutsumi, A., Shimazu, M., Nagami, M., \& Shimazu, A. (2007). Development of a mental health action checklist for improving workplace environment as means of job stress prevention. Sangyo Eiseigaku Zasshi, 49(4), 127-142. 